Check for updates

Cite this: RSC Adv., 2017, 7, 34618

Received 9th May 2017

Accepted 5th July 2017

DOI: $10.1039 / \mathrm{c} 7 \mathrm{ra05208a}$

rsc.li/rsc-advances

\section{Niobium-doped titanium dioxide on a functionalized carbon supported palladium catalyst for enhanced ethanol electro-oxidation $\uparrow$}

\begin{abstract}
Weichuan Xu, ${ }^{a}$ Litao Yan, ${ }^{a}$ Huiqiang Wang, ${ }^{b}$ Steven Liaw ${ }^{a}$ and Hongmei Luo (iD *a
$\mathrm{Pd}$ nanoparticles anchored on $\mathrm{Nb}$-doped $\mathrm{TiO}_{2}$ with functionalized carbon support (denoted as $\mathrm{Pd} / \mathrm{Nb}-$ $\mathrm{TiO}_{2}-\mathrm{C}$ ) is synthesized through a controllable hydrolysis and impregnation method. The as-synthesized catalyst is characterized by X-ray diffraction (XRD), X-ray photoelectron spectroscopy (XPS), and transmission electron microscopy (TEM). Pd nanoparticles exhibit a uniform distribution with an average particle size of $3 \mathrm{~nm}$. The electrochemical performance is tested by cyclic voltammetry (CV) and chronoamperometry (CA). Compared with $\mathrm{Pd}$ supported by functionalized carbon ( $\mathrm{Pd} / \mathrm{C}), \mathrm{Pd} / \mathrm{Nb}-\mathrm{TiO}_{2}-$ C demonstrates 15.7\% higher metallic Pd content, 23\% higher electrochemical active surface area, 75\% higher current density in ethanol electro-oxidation, 5\% higher durability, and better tolerance of carbonaceous species. The performance enhancement is attributed to the increased conductivity from $\mathrm{Nb}$-doping and the synergistic effect between $\mathrm{Pd}$ and $\mathrm{TiO}_{2}$.
\end{abstract}

\section{Introduction}

The direct ethanol fuel cell (DEFC) is a clean energy generation device in terms of environmental benignity compared with fossil fuel based energy sources. As a type of direct alcohol fuel cell, DEFCs have advantages over other renewable fuel sources. Ethanol, with a relatively higher $\mathrm{H} / \mathrm{C}$ ratio in its molecules, presents higher energy density (26.4 $\mathrm{MJ} \mathrm{kg}^{-1}$ ) compared with methanol (19.7 $\mathrm{MJ} \mathrm{kg}^{-1}$ ). Fewer health issues are recorded for ethanol in either electro-oxidation processes or daily contact. ${ }^{1}$ Large quantities of ethanol can be obtained from biomass fermentation, ${ }^{2}$ giving it incomparably wide availability. These factors ensure ethanol as a suitable fuel in clean renewable energy devices. Among all the catalysts for ethanol electrooxidation, noble metals i.e. platinum $(\mathrm{Pt}),{ }^{3-5}$ palladium $(\mathrm{Pd}),{ }^{6,7}$ ruthenium $(\mathrm{Ru}),^{8,9}$ rhodium $(\mathrm{Rh})^{\mathbf{9 , 1 0}}$ and iridium (Ir) ${ }^{11,12}$ along with their combinations have been widely investigated because of their superior performance. Compared with Pt, Pd has higher abundance and shows much more active electrocatalytic ability in basic solutions due to its higher oxophilicity and relatively

${ }^{a}$ Department of Chemical and Materials Engineering, New Mexico State University, New Mexico 88003, USA. E-mail: hluo@nmsu.edu

${ }^{b}$ College of Mechanical and Electrical Engineering, Agricultural University of Hebei, Baoding 071001, China

$\dagger$ Electronic supplementary information (ESI) available: HRTEM, energy-dispersive X-ray spectroscopy, SEM with EDS mapping of $\mathrm{Pd} / \mathrm{Nb}-\mathrm{TiO}_{2}-\mathrm{C}$. $\mathrm{CV}$ of functionalized carbon and niobium-doped titanium dioxide on functionalized carbon $\left(\mathrm{Nb}-\mathrm{TiO}_{2}-\mathrm{C}\right)$ in $1 \mathrm{M} \mathrm{KOH}$ and $1 \mathrm{M}$ ethanol solution. The ethanol electro-oxidation by $\mathrm{Pd} / \mathrm{Nb}-\mathrm{TiO}_{2}-\mathrm{C}$ in $1 \mathrm{M} \mathrm{KOH}$ solution with different ethanol concentrations with a scan rate of $20 \mathrm{mV} \mathrm{\textrm {s } ^ { - 1 }}$. See DOI: 10.1039/c7ra05208a inert nature. ${ }^{\mathbf{1 3 , 1 4}}$ Bi-metallic and tri-metallic catalyst usually have higher electrochemical activity and better stability over single noble metal because of their increased ability of breaking $\mathrm{C}-\mathrm{C}$ bonds and its blocking effect of further oxidation of poisoning species. ${ }^{15}$

To fully utilize and maintain their catalytic ability of precious metals, catalyst support with large surface area is required to uniformly disperse catalysts. Carbon black has been identified as a classic alcohol cell catalyst support due to its high electroconductivity ${ }^{16}$ and large surface area. ${ }^{17}$ Typically, functionalized carbon is acid-treated carbon, where oxidative functional groups ${ }^{\mathbf{1 8}}$ are introduced, and this support can further increase solubility and density of catalyst reaction sites. ${ }^{16}$ Carbon alone however suffers from fast degradation and low electrochemical stability, especially at high potential in alkaline media. Carbon oxidation reaction in high $\mathrm{pH}$ environment is shown below: ${ }^{16}$

$$
\mathrm{C}+6 \mathrm{OH}^{-} \rightarrow \mathrm{CO}_{3}^{2-}+3 \mathrm{H}_{2} \mathrm{O}+4 \mathrm{e}^{-}
$$

Therefore, the search of a catalyst support with corrosion resistance in electrolyte, during alcohol electro-oxidation, is demanded. To tackle the corrosion problem, transition metal oxides such as $\mathrm{TiO}_{2},{ }^{19-21} \mathrm{WO}_{3},{ }^{22-24}$ and $\mathrm{V}_{2} \mathrm{O}_{5}$ (ref. 25-27) offer high stability in both acidic and alkaline media. $\mathrm{TiO}_{2}$ stands out as a dominating candidate for electro-catalyst support due to their superiorities in many aspects. Corrosion resistant $\mathrm{TiO}_{2}$ can dramatically increase cycle numbers and catalyst efficiency in the long run. Also, $\mathrm{TiO}_{2}$-based material is noted for its contribution to strong metal-support interaction (SMSI) and three-phase junction, ${ }^{28}$ i.e. junction of carbon, $\mathrm{TiO}_{2}$ and $\mathrm{Pd} / \mathrm{Pt}$. Pt immobilized on high niobium content rutile titania and 
carbon nanotubes shows smaller particle size, narrower and more uniform distribution. ${ }^{5}$ Produced by either photoreduction method $^{29}$ or hydrothermal synthesis, ${ }^{30}$ the three-phase junction effect on the electrochemical performance is beneficial owing to more catalyst exposure, less agglomeration of catalyst nanoparticles, and extended catalyst life span. However, $\mathrm{TiO}_{2}$ has relatively low surface area ${ }^{31}$ and low electro-conductivity. ${ }^{32}$ One way to increase its conductivity is utilizing sub-stoichiometric $\mathrm{TiO}_{2-x}$, but it can be oxidized to $\mathrm{TiO}_{2}$ in fuel cell operation condition. ${ }^{3,34}$ Another method to lower impedance is to dope with a donor type metal. ${ }^{35}$ Typically, $\mathrm{Nb}$ has one free electron in the outer shell when it is doped into $\mathrm{TiO}_{2}$ lattice. ${ }^{16,36}$ It has been reported that doping 10 at $\% \mathrm{Nb}$ into $\mathrm{TiO}_{2}$ would increase its conductivity by $\sim 1600$ fold.$^{16}$ Besides, Nb-doping decreases the particle size of $\mathrm{TiO}_{2}$ and increases its surface area. However, increasing the doping amount by over $30 \%$ would damage the crystal structure of $\mathrm{TiO}_{2}$, thus reducing the stability of catalyst support. ${ }^{16}$ We herein report Nb-doped $\mathrm{TiO}_{2}$ on functionalized carbon supported Pd catalyst for electro-oxidation of ethanol in alkaline media. As compared with the functionalized carbon supported Pd catalyst, it shows higher ethanol electro-oxidation current density and higher durability, thanks from the increased conductivity from Nb-doping and the synergistic effect between $\mathrm{Pd}$ and $\mathrm{TiO}_{2}$.

\section{Experimental}

\subsection{Material synthesis}

Functionalized carbon. Functionalized carbon was prepared by acid treatment of XC-72 carbon black (FUELCELL). $200 \mathrm{mg}$ $\mathrm{XC}-72$ carbon was dissolved in $30 \mathrm{ml}$ nitric acid (ACS reagent, $70 \%$, Sigma-Aldrich) and $90 \mathrm{ml}$ sulfuric acid (ACS reagent, 95$98 \%$, Sigma-Aldrich) for $2 \mathrm{~h}$ with continuous sonication. Black solution was diluted with $180 \mathrm{ml}$ DI water. Functionalized carbon was collected by centrifuge, washed with DI water and dried in vacuum oven at $50{ }^{\circ} \mathrm{C}$ overnight.

Nb-TiO $-\mathbf{C}$ support. $\mathrm{Nb}_{2}-\mathrm{TiO}_{2}-\mathrm{C}$ support was prepared through decomposition of titanium(Iv) isopropoxide (97\%, Sigma-Aldrich) and niobium(v) ethoxide (99.95\%, SigmaAldrich) with DI water. $50 \mathrm{mg}$ functionalized carbon was dissolved and sonicated in $20 \mathrm{ml}$ ethanol with $1 \mathrm{ml}$ DI water. $100 \mu \mathrm{l}$ titanium isopropoxide(Iv) was dissolved in $10 \mathrm{ml}$ ethanol and 10 $\mu \mathrm{l}$ niobium(v) ethoxide was dissolved in $1 \mathrm{ml}$ ethanol. The mixture of these three solutions underwent stirring for $4 \mathrm{~h}$. The sample was then filtrated, washed with ethanol and vacuum dried at $50{ }^{\circ} \mathrm{C}$ overnight.

$\mathbf{P d} / \mathbf{N b}-\mathbf{T i O}_{2}-\mathbf{C}$ catalyst. $4 \mathrm{mg}$ sodium tetrachloropalladate(II) (98\%, Sigma-Aldrich) was dissolved in $10 \mathrm{ml}$ DI water with $20 \mathrm{mg} \mathrm{Nb}-\mathrm{TiO}_{2}-\mathrm{C}$ support. The solution was then stirred and heated at $100{ }^{\circ} \mathrm{C}$ until water was evaporated. After filtration, washing and drying of the sample, forming gas $\left(6 \% \mathrm{H}_{2}\right.$ and $94 \%$ argon) was used at $450{ }^{\circ} \mathrm{C}$ to reduce palladium oxides to metallic $\mathrm{Pd}$ and also to activate $\mathrm{Nb}$-doped anatase $\mathrm{TiO}_{2}$. Similarly, Pd on functionalized carbon $(\mathrm{Pd} / \mathrm{C})$ was synthesized according to procedures above without addition of titanium(Iv) isopropoxide and niobium(v) ethoxide.

\subsection{Materials characterization}

Phase and crystal structure of $\mathrm{Pd} / \mathrm{Nb}-\mathrm{TiO}_{2} / \mathrm{C}$ and $\mathrm{Pd} / \mathrm{C}$ were analyzed with X-ray diffraction (XRD) on a MINIFlex II, Rigaku, using filtered $\mathrm{Cu} \mathrm{K} \alpha$ radiation $(\lambda=1.54005 \AA)$ at $30 \mathrm{kV}$ and 15 $\mathrm{mA}$. The morphology was investigated by transmission electron microscopy (TEM) on H-7650, Hitachi High-Technologies Corp. The TEM used an accelerating voltage at $80 \mathrm{kV}$ with an integrated, side-mounted CCD digital image camera system. EDS mapping was conducted on a S-3400N Type II scanning electron microscope (Hitachi High-Technologies Corp.). X-Ray photoelectron spectroscopy (XPS) was tested on an AXIS ULTRA X-ray Photoelectron Spectrometer with Al monochromatic X-ray by Kratos Analytical. C 1s peak was used as a reference.

\subsection{Electrochemical characterization}

The glassy carbon electrode was polished with 5, 0.3, and 0.05 $\mu \mathrm{m} \mathrm{Al}_{2} \mathrm{O}_{3}$ solution (Allied) in sequence. It was then cleaned by sonication and dried with compressed air. To prepare catalyst ink, $10 \mathrm{mg} \mathrm{Pd} / \mathrm{Nb}-\mathrm{TiO}_{2}-\mathrm{C}$ was dissolved in $2 \mathrm{ml} 0.05 \mathrm{wt} \%$ Nafion solution, which was $\sim 5$ wt\% Nafion ${ }^{\circledR} 117$ solution (Sigma-Aldrich) diluted 100 times by DI water. After sonication, $20 \mu$ l catalyst ink was dropped onto the glassy carbon electrode of $5 \mathrm{~mm}$ diameter with micropipette. The loading of $\mathrm{Pd}$ for both catalysts on the electrode is around $0.035 \mathrm{mg} \mathrm{cm}^{-2}$. The electrode was dried at room temperature overnight. Electrochemical tests were carried out with MSR Rotator, PINE research and CHI 600 electrochemical workstation. Three electrodes setup, i.e. working electrode, Pt coil counter electrode and silver chloride $\mathrm{Ag} / \mathrm{AgCl}$ (4 M) reference electrode were used at room temperature.

\section{Results and discussion}

\subsection{Structure and morphology}

Fig. 1 shows the XRD pattern of the as-synthesized $\mathrm{Pd} / \mathrm{Nb}-\mathrm{TiO}_{2}-$ C. Peaks of face centered cubic $\mathrm{Pd}$ and Anatase $\mathrm{TiO}_{2}$ can be

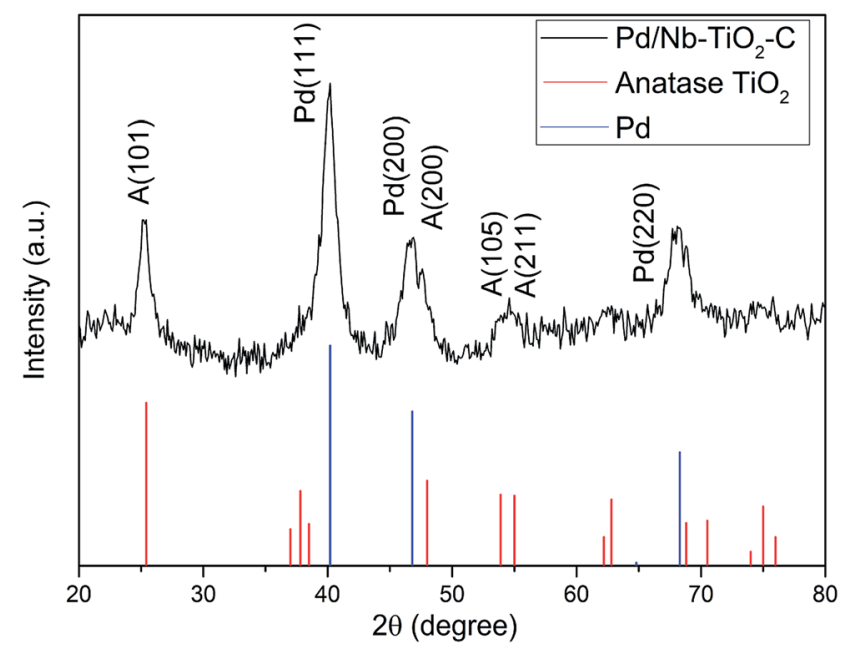

Fig. 1 XRD pattern of $\mathrm{Pd} / \mathrm{Nb}-\mathrm{TiO}_{2}-\mathrm{C}$ and $\mathrm{PDF}$ cards of anatase $\mathrm{TiO}_{2}$ and fcc Pd. 
indexed by PDF\#98-000-0344 and PDF\#98-000-0081, respectively. No peaks of niobium oxides or metallic $\mathrm{Nb}$ can be found. Lattice parameters of $\mathrm{TiO}_{2}$ are $a=3.798 \AA$ and $c=9.547 \AA$. Since the ionic size of $\mathrm{Nb}^{4+}$ is $82 \mathrm{pm}, 10.1 \%$ bigger than that of $\mathrm{Ti}^{4+}$, the enlarged lattice parameters $(+0.34 \%$ for $a$ and $+0.35 \%$ for $c)$ compared with ref. 37 indicate $\mathrm{Nb}$ incorporation into $\mathrm{TiO}_{2}$. $\mathrm{Pd}$ (111), (200) and (220) surfaces reveal face centered cube (fcc) structure. Using Sherrer's equation on (111) plane shows that $\mathrm{Pd}$ in $\mathrm{Pd} / \mathrm{Nb}-\mathrm{TiO}_{2}-\mathrm{C}$ has a crystallite size of $\sim 6.0 \mathrm{~nm}$, with lattice parameter of $a=3.88 \AA$, close to $3.86 \AA$ in ref. 38 .

Morphology and Pd particle size were investigated by TEM. Fig. 2 shows the TEM images of $\mathrm{Nb}-\mathrm{TiO}_{2}-\mathrm{C}$ support, $\mathrm{Pd} / \mathrm{Nb}-$ $\mathrm{TiO}_{2}-\mathrm{C}$, and $\mathrm{Pd} / \mathrm{C}$. In Fig. 2(a) $\mathrm{Nb}-\mathrm{TiO}_{2}-\mathrm{C}$ shows multilayer structure with thickness around $40 \mathrm{~nm}$. It can be seen that the Pd nanoparticles exhibit uniform dispersion on both supports $\mathrm{Nb}-\mathrm{TiO}_{2}-\mathrm{C}$ and $\mathrm{C}$, with average diameter of $2.8 \mathrm{~nm}$ and $3.2 \mathrm{~nm}$ (14\% bigger), respectively. The finer Pd nanoparticle formation in the former sample can be explained by the three-phase junction, (three-phase means $\mathrm{Pd}, \mathrm{TiO}_{2}$ and $\mathrm{C}$ ) which prevents the catalyst from agglomeration. ${ }^{39}$ HRTEM, Energy-dispersive Xray spectroscopy (EDS) and elemental mapping of $\mathrm{Pd} / \mathrm{Nb}-\mathrm{TiO}_{2}-$ $\mathrm{C}$ were conducted to further investigate the microstructure and element distribution, as shown in Fig. S1-S3.† The EDS mapping demonstrates that $\mathrm{Pd}, \mathrm{Nb}, \mathrm{Ti}, \mathrm{O}$, and $\mathrm{C}$ elements were uniformly distributed in the sample and the weight percentages of elements are listed in Table 1 . The numbers are consistent

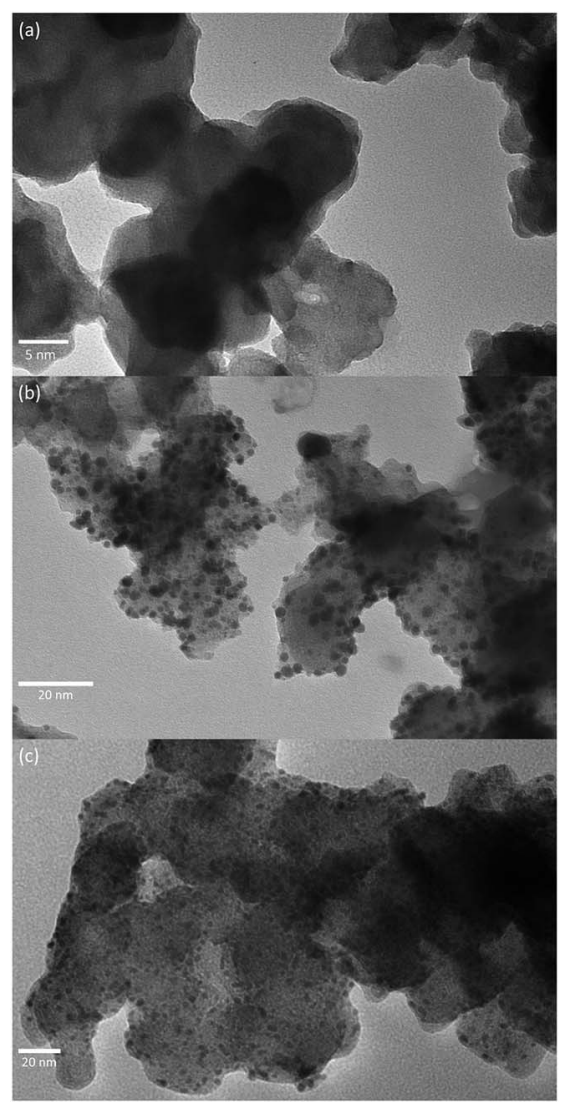

Fig. 2 TEM images of (a) $\mathrm{Nb}-\mathrm{TiO}_{2}-\mathrm{C}$ support, (b) $\mathrm{Pd} / \mathrm{Nb}-\mathrm{TiO}_{2}-\mathrm{C}$, and (c) $\mathrm{Pd} / \mathrm{C}$ (scale bars: $5 \mathrm{~nm}, 20 \mathrm{~nm}$, and $20 \mathrm{~nm}$, respectively).
Table 1 Element weight percentages by EDS mapping

\begin{tabular}{lcc}
\hline Element line & Element wt\% & wt\% error \\
\hline C K & 60.77 & \pm 6.77 \\
O K & 14.37 & \pm 0.83 \\
Ti K & 13.26 & \pm 0.72 \\
Nb L & 4.47 & \pm 0.45 \\
Pd L & 7.13 & \pm 1.04
\end{tabular}

with theoretical values of $6.7 \mathrm{wt} \% \mathrm{Pd}$ and $33 \mathrm{wt} \% \mathrm{Nb}-\mathrm{TiO}_{2}$. Metal oxide with carbon not only facilitate Pd deposition on the catalyst support during preparation, ${ }^{29}$ but also hinder catalyst migration in electrochemical reactions. ${ }^{40}$

$\mathrm{X}$-ray photoelectron spectroscopy was carried out to evaluate the functional groups on carbon and to better understand the synergistic effect between $\mathrm{TiO}_{2}$ and Pd. Fig. 3(a) is C 1s XPS spectrum with peak fitting in $\mathrm{Pd} / \mathrm{Nb}-\mathrm{TiO}_{2}-\mathrm{C}$. Peaks from the low to the high binding energies can be attributed to $\mathrm{C}-\mathrm{C} \mathrm{sp}^{2}$, $\left.\mathrm{C}-\mathrm{C} \mathrm{sp}{ }^{3}, \mathrm{C}-\mathrm{OH}, \mathrm{C}-\mathrm{O}-\mathrm{C},\right\rangle \mathrm{C}=\mathrm{O}$ and $\mathrm{COOH}$ functional groups. ${ }^{41}$ The hydrophilic groups not only increase solubility, but also give more anchoring and reactive sites for the catalyst. Fig. 3(b and c) show XPS spectra of Pd 3d of $\mathrm{Pd} / \mathrm{Nb}-\mathrm{TiO}_{2}-\mathrm{C}$ and $\mathrm{Pd} / \mathrm{C}$, each deconvoluted into three pairs of doublets, i.e. metallic $\mathrm{Pd}^{0}, \mathrm{Pd}^{2+}$ and $\mathrm{Pd}^{4+}$ species. $\mathrm{Pd} / \mathrm{C}$ shows $25.1 \% \mathrm{Pd}^{0}$ at $335.0 \mathrm{eV}$, $13.4 \% \mathrm{Pd}^{2+}$ at $335.8 \mathrm{eV}$ and $61.4 \% \mathrm{Pd}^{4+}$ at $336.6 \mathrm{eV}$, while $40.8 \%$ $\mathrm{Pd}^{0}, 27.7 \% \mathrm{Pd}^{2+}$ and $31.4 \% \mathrm{Pd}^{4+}$ are found for $\mathrm{Pd} / \mathrm{Nb}-\mathrm{TiO}_{2}-\mathrm{C}$. The $30 \%$ decrease of $\mathrm{Pd}^{4+}$ and $15.7 \%$ increase of metallic $\mathrm{Pd}^{0}$ shift Pd $3 \mathrm{~d}_{5 / 2}$ peaks to weaker binding energy levels, resulting in the improved metallic catalyst surface area and the decreased adsorption of carbonaceous poisoning chemicals on catalyst surface. $^{42}$

\subsection{Electrochemical performance}

Cyclic voltammetry (CV) was performed in $1 \mathrm{M} \mathrm{KOH}$ solution for $\mathrm{Pd} / \mathrm{Nb}-\mathrm{TiO}_{2}-\mathrm{C}$ and $\mathrm{Pd} / \mathrm{C}$. The similar CV patterns in Fig. 4(a) for both samples show typical Pd activity in alkaline media. ${ }^{43}$ In the cathodic scan, peak at $-0.35 \mathrm{~V}(v s$. $\mathrm{Ag} / \mathrm{AgCl})$ reflects the reduction of palladium oxide into $\mathrm{Pd}$; the stronger reduction peak for $\mathrm{Pd} / \mathrm{Nb}-\mathrm{TiO}_{2}-\mathrm{C}$ suggests higher Pd catalyst activity and larger electrochemical active surface area (ECSA) due to the reduced Pd oxidation state and smaller particle size of catalyst, consistent with XPS analysis and TEM observation. Increased ECSA is fundamental for high power energy device considering density of reaction sites. The small peaks at $-0.18 \mathrm{~V}$ for both catalysts could be attributed to the reduction of dissolved oxygen by carbon. With the small reduction peak taken into consideration, electrochemical active surface areas of $\mathrm{Pd} / \mathrm{C}$ and $\mathrm{Pd} / \mathrm{Nb}-$ $\mathrm{TiO}_{2}-\mathrm{C}$ are calculated by the charge integration of the reduction peak in $\mathrm{CV}$ as $0.96 \mathrm{mC} \mathrm{cm}^{-2}$ and $1.17 \mathrm{mC} \mathrm{cm}^{-2}$, respectively.

To unveil ethanol electro-oxidation activity, CVs for catalysts in $1 \mathrm{M} \mathrm{KOH}$ in ethanol were tested. As a comparison, CVs of functionalized carbon, $\mathrm{Nb}-\mathrm{TiO}_{2}-\mathrm{C}$ support and ethanol concentration effect on $\mathrm{Pd} / \mathrm{Nb}-\mathrm{TiO}_{2}-\mathrm{C}$ are presented in Fig. $\mathrm{S} 4 . \dagger$ No oxidation peak was observed in the low concentration of ethanol of $0.001 \mathrm{M}$. Peaks can be identified in the $0.01 \mathrm{M}$ 

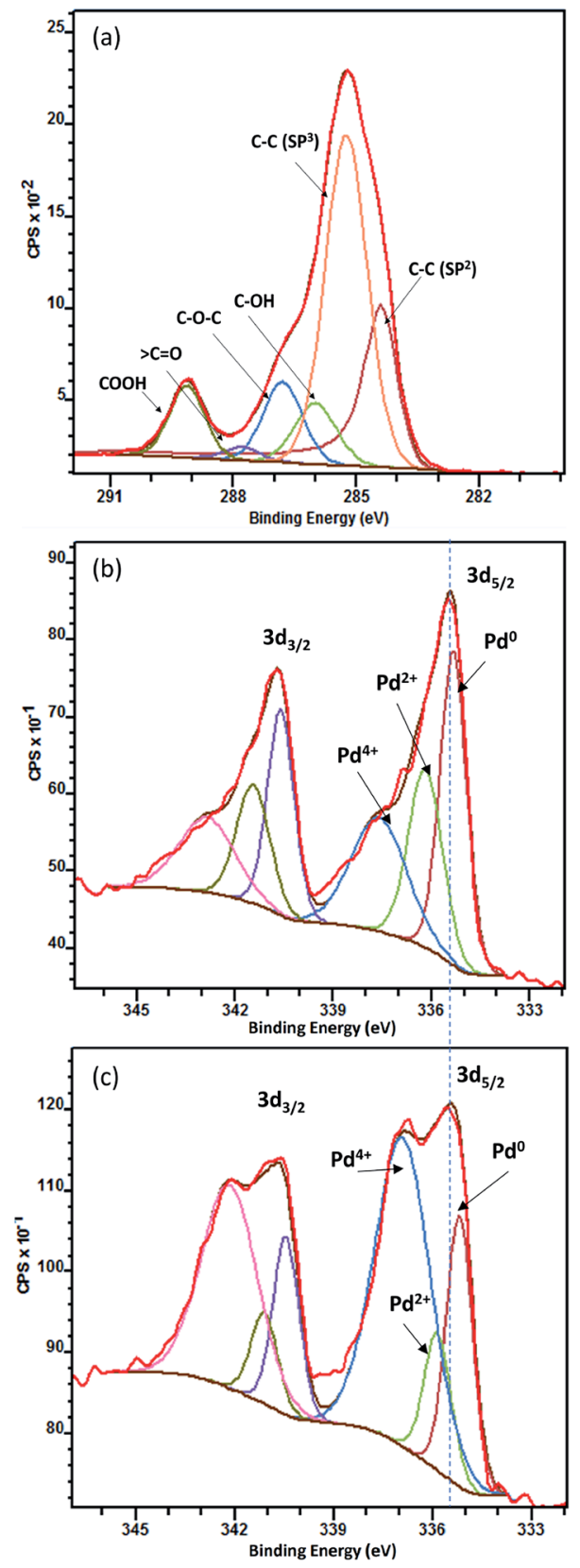

Fig. 3 XPS of $\mathrm{C}$ 1s of $\mathrm{Pd} / \mathrm{Nb}-\mathrm{TiO}_{2}-\mathrm{C}$ (a), $\mathrm{Pd} 3 \mathrm{~d}$ of $\mathrm{Pd} / \mathrm{Nb}-\mathrm{TiO}_{2}-\mathrm{C}$ (b) and $\mathrm{Pd} / \mathrm{C}(\mathrm{c})$.

ethanol and peaks are of similar shape in $0.1,1$ and $2 \mathrm{M}$ ethanol solutions, indicative of practical ethanol electro-oxidation range from 0.1 to $2 \mathrm{M}$. In the following experiments, $1 \mathrm{M} \mathrm{KOH}$ and $1 \mathrm{M}$ ethanol solution was chosen. First, scan rate influence of ethanol electro-oxidation was investigated on $\mathrm{Pd} / \mathrm{Nb}-\mathrm{TiO}_{2}-\mathrm{C}$ catalyst. As shown in Fig. 4(b), both the anodic current density and cathodic current density increase when the scan rate increases from 10 to $200 \mathrm{mV} \mathrm{s}^{-1}$. The insert figure demonstrates a linear relationship between the anodic current density and the square root of scan rate, indicative of diffusion controlled reaction kinetics. Further ethanol electro-oxidation results are shown in ECSA and electrode area normalized CV in Fig. 4(c) and ECSA and Pd mass normalized CV in Fig. 4(d). In the forward scan, ethanol chemisorbed on the catalyst surface is oxidized, whereas in the reverse sweep, oxidation of carbonaceous species occurs. The ratio of the forward sweep peak current $i_{\mathrm{f}}$ to the reverse scan peak current $i_{\mathrm{b}}$ represents the tolerance of catalyst poisoning, and a higher $i_{\mathrm{f}} / i_{\mathrm{b}}$ indicates more complete oxidation of ethanol and less accumulation of carbonaceous chemicals. ${ }^{43}$ Though with a $0.04 \mathrm{~V}$ positively shifted ethanol oxidation peak, $\mathrm{Pd} / \mathrm{Nb}-\mathrm{TiO}_{2}-\mathrm{C}$ shows $i_{\mathrm{f}}$ of 0.088 $\mathrm{A} \mathrm{cm}^{-2}, 47 \%$ higher than $0.06 \mathrm{~A} \mathrm{~cm}^{-2}$ of Pd/C. The massive increase in ethanol oxidation current density is mainly explained by $23 \%$ higher ECSA of metallic Pd catalyst and the synergistic effect between $\mathrm{Pd}$ and $\mathrm{Nb}-\mathrm{TiO}_{2}$. Strong metalsupport interaction is responsible for higher metallic catalyst content and immobilized catalyst during electro-oxidation. Besides, the $i_{\mathrm{f}} / i_{\mathrm{b}}$ ratio of $\mathrm{Pd} / \mathrm{Nb}-\mathrm{TiO}_{2}-\mathrm{C}$ reaches 0.7 , while the value of $\mathrm{Pd} / \mathrm{C}$ is only 0.44 . The ratio raise can be explained by the reduced noble metal bonding energy with adsorbed carbonaceous chemicals, ${ }^{44}$ which is the reason of $0.02 \mathrm{~V}$ positively shifted backward scan peak in $\mathrm{Pd} / \mathrm{Nb}-\mathrm{TiO}_{2}-\mathrm{C}$. A lower $i_{\mathrm{f}} / i_{\mathrm{b}}$ ratio in $\mathrm{Pd} / \mathrm{C}$ causes accumulation of poisoning species in electrolyte, leading to inefficient oxidation of irrelevant organics, degradation of catalyst, power loss and energy waste. Due to varying operating conditions such as catalyst content and electrolyte concentration, it is difficult to directly compare $i_{\mathrm{f}} / i_{\mathrm{b}}$ ratio of catalysts among different works. Based on similar Pd/C catalysts, comparing the $i_{\mathrm{f}} / i_{\mathrm{b}}$ ratio could help to eliminate effects of interfering factors. In our work, $\mathrm{Pd} / \mathrm{Nb}-\mathrm{TiO}_{2}-\mathrm{C}$ has $\sim 60 \% i_{\mathrm{f}} / i_{\mathrm{b}}$ increase, much higher than $23 \%$ from Pd on carbon-doped $\mathrm{TiO}_{2}{ }^{43} 46 \%$ from Ni@Pd core-shell nanoparticles on multiwalled carbon nanotubes ${ }^{45}$ and few works with decreased $i_{\mathrm{f}} /$ $i_{\mathrm{b}} \cdot{ }^{16,46}$ The high $i_{\mathrm{f}} / i_{\mathrm{b}}$ ratio increase could be attributed to the synergistic effect with high $\mathrm{TiO}_{2}:$ Pd molar ratio around $6.2: 1$ in our work, which reduces $\mathrm{Pd}^{2+}$ and $\mathrm{Pd}^{4+}$ dramatically. In Fig. $4(\mathrm{~d}), \mathrm{Pd} / \mathrm{Nb}^{-} \mathrm{TiO}_{2}-\mathrm{C}$ reaches $2.6 \mathrm{~A} \mathrm{mg}_{\mathrm{Pd}}{ }^{-1}$ in the forward scan, $45 \%$ higher than that of $\mathrm{Pd} / \mathrm{C}$, which is consistent with the result in Fig. 4(c), and the current density scale matches that in literature. ${ }^{43}$ It is noted that the same origin was reported for the forward oxidation peak and backward oxidation peak by methanol electro-oxidation reaction with Pt-based catalysts in acidic media. ${ }^{47}$ In this work ethanol electro-oxidation with Pdbased catalysts was conducted in alkaline media. Since similar principles might apply even in different conditions, the origin of the forward scan current and backward scan current in ethanol and alkaline media needs detailed investigation.

Stability of $\mathrm{Pd} / \mathrm{C}$ and $\mathrm{Pd} / \mathrm{Nb}-\mathrm{TiO}_{2}-\mathrm{C}$ was tested by chronoamperometry in a solution containing $1 \mathrm{M} \mathrm{KOH}$ and $1 \mathrm{M}$ ethanol at $-0.2 \mathrm{~V} v s$. Ag/AgCl. Results indicate that $\mathrm{Pd} / \mathrm{C}$ lost $50 \%$ initial current density after $150 \mathrm{~s}$, while $\mathrm{Pd} / \mathrm{Nb}-\mathrm{TiO}_{2}-\mathrm{C}$ lasted another $100 \mathrm{~s}$ before it lost half of its catalytic ability. Besides, $\mathrm{Pd} / \mathrm{Nb}-\mathrm{TiO}_{2}-\mathrm{C}$ catalyst could possibly degrade faster than $\mathrm{Pd} / \mathrm{C}$ considering much higher initial current density at $-0.2 \mathrm{~V}$ in Fig. $5(\mathrm{a})$, because intensive surface reactions usually cause severe particle aggregation on the working electrode. After $3000 \mathrm{~s}, \sim 94 \%$ ethanol oxidation current lost for Pd/C catalyst in Fig. $5(\mathrm{~b})$, and $\sim 5 \%$ higher current retention was observed for $\mathrm{Pd} / \mathrm{Nb}-\mathrm{TiO}_{2}-\mathrm{C}$. The better reserved activity of $\mathrm{Pd} /$ 

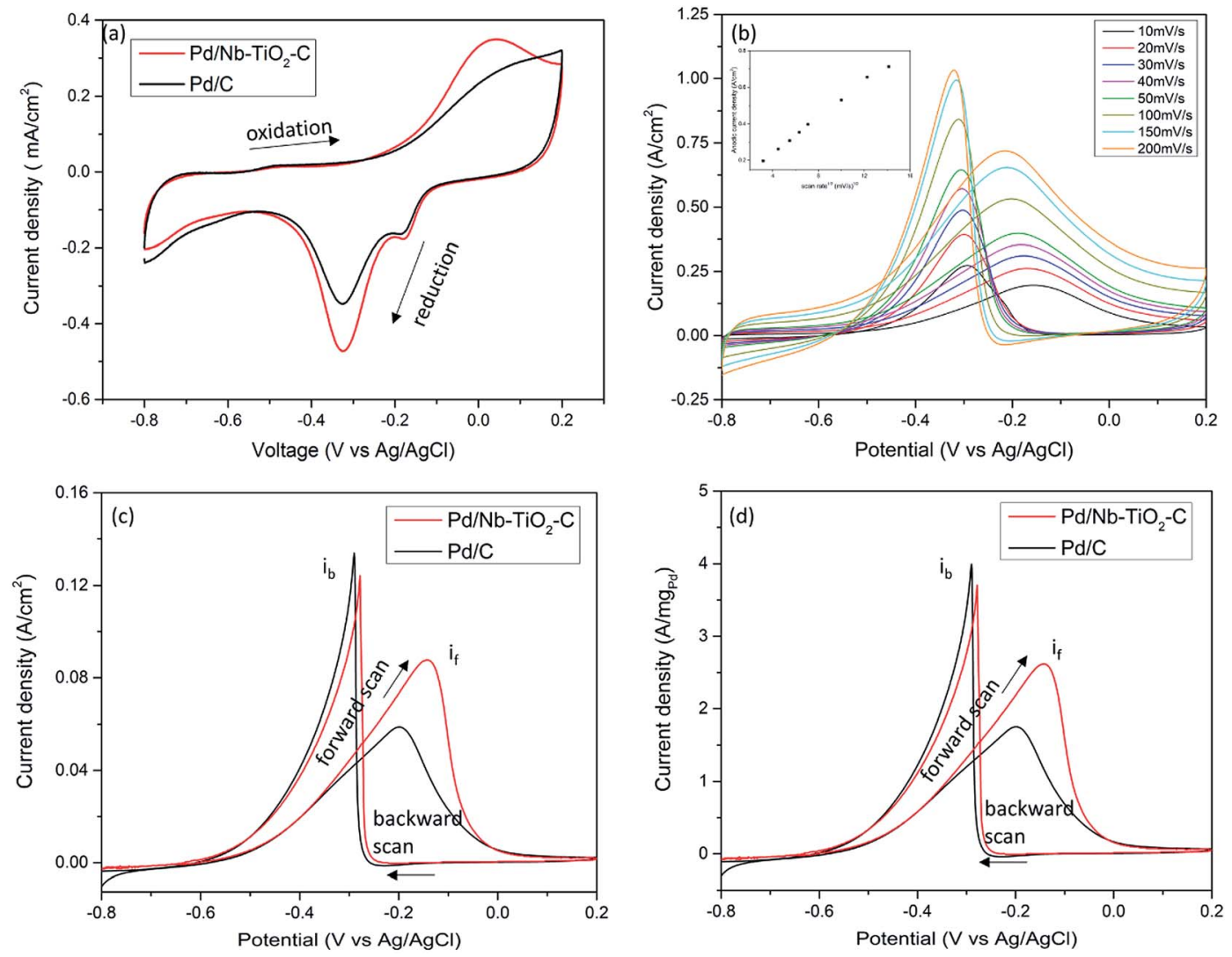

Fig. 4 (a) $\mathrm{CV}$ of $\mathrm{Pd} / \mathrm{Nb}-\mathrm{TiO}_{2}-\mathrm{C}$ and $\mathrm{Pd} / \mathrm{C}$ in $1 \mathrm{M} \mathrm{KOH}$ with a scan rate of $20 \mathrm{mV} \mathrm{s}^{-1}$; (b) $\mathrm{CV}$ of $\mathrm{Pd} / \mathrm{Nb}-\mathrm{TiO}_{2}-\mathrm{C}$ in $1 \mathrm{M} \mathrm{KOH}$ and $1 \mathrm{M}$ ethanol solution with different scan rates. Insert of (b) is anodic scan current density vs. scan rate ${ }^{1 / 2}$; (c) $\mathrm{ECSA}$ and electrode area normalized $\mathrm{CV}$ of $\mathrm{Pd} / \mathrm{Nb}-\mathrm{TiO}{ }_{2}-\mathrm{C}$ and $\mathrm{Pd} / \mathrm{C}$ in $1 \mathrm{M} \mathrm{KOH}$ and $1 \mathrm{M}$ ethanol solution with a scan rate of $20 \mathrm{mV} \mathrm{s}^{-1}$; and (d) ECSA and palladium mass normalized CV of $\mathrm{Pd} / \mathrm{Nb}-\mathrm{TiO}{ }_{2}-\mathrm{C}$ and $\mathrm{Pd} / \mathrm{C}$ in $1 \mathrm{M} \mathrm{KOH}$ and $1 \mathrm{M}$ ethanol solution with a scan rate of $20 \mathrm{mV} \mathrm{s}^{-1}$.
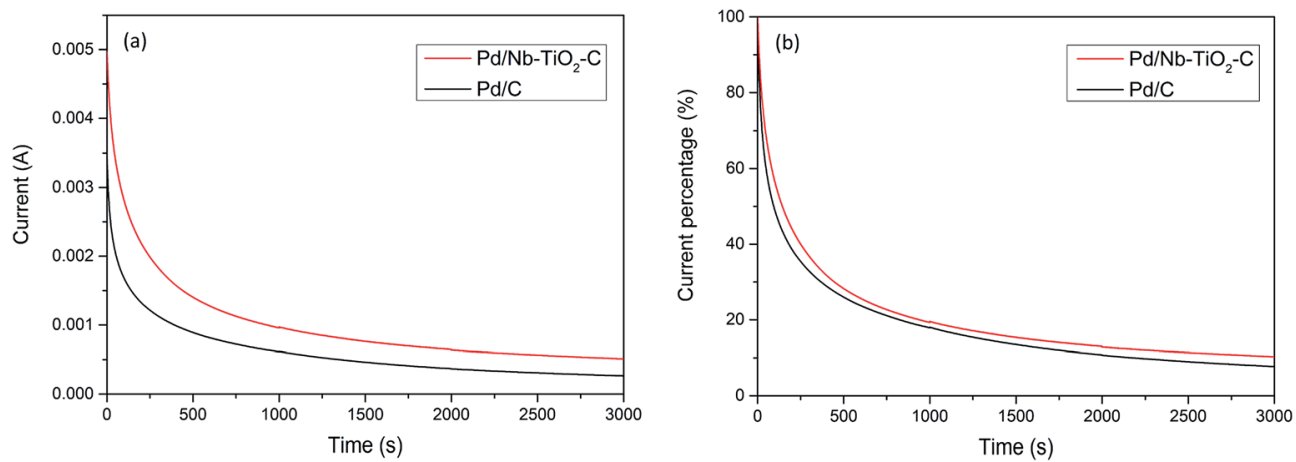

Fig. 5 Chronoamperometry (CA) of $\mathrm{Pd} / \mathrm{Nb}-\mathrm{TiO}_{2}-\mathrm{C}$ and $\mathrm{Pd} / \mathrm{C}$ in $1 \mathrm{M} \mathrm{KOH}$ and $1 \mathrm{M}$ ethanol solution at $-0.2 \mathrm{~V}$ for 3000 seconds for (a) currenttime curve and (b) current percentage-time curve.

$\mathrm{Nb}-\mathrm{TiO}_{2}-\mathrm{C}$ after long period of reaction can be attributed to the synergistic effect between the catalyst and the support. It was assumed that the size of Pd nanoparticles gradually grows after reactions. ${ }^{48}$ Loss of electrochemical active surface area during reaction and dissolution of active materials are two direct reasons for the slow oxidation rate. It is inferred that $\mathrm{TiO}_{2}$ and functionalized carbon around Pd nanoparticles prevent catalyst from agglomeration, which helps to preserve Pd catalytic ability in the durability test.

\section{Conclusions}

In this work, Nb-doped $\mathrm{TiO}_{2}$ on functionalized carbon supported $\mathrm{Pd}$ catalyst is synthesized and tested against $\mathrm{Pd} / \mathrm{C}$. $\mathrm{Pd} /$ $\mathrm{Nb}-\mathrm{TiO}_{2}-\mathrm{C}$ catalyst shows $14 \%$ smaller Pd particle size, $23 \%$ higher electrochemical active surface area, $75 \%$ higher ethanol electro-oxidation current density and 5\% more catalyst stability after chronoamperometry. The synergistic effect including electron transfer from $\mathrm{TiO}_{2}$ to $\mathrm{Pd}$ and the three-phase junction 
by $\mathrm{C}, \mathrm{TiO}_{2}$ and $\mathrm{Pd}$ account for higher metallic catalyst ECSA, finer catalyst size, and less sample degradation leading to better electrochemical performance.

\section{Acknowledgements}

Dr Luo thanks the support from New Mexico EPSCoR (NSF1301346) and the USDA National Institute of Food and Agriculture, HSI Collaboration: Integrating Food Science/ Engineering and Education Network (IFSEEN, award number: 2015-38422-24059).

\section{References}

1 D. Collister, G. Duff, W. Palatnick, P. Komenda, N. Tangri and J. Hingwala, Am. J. Kidney Dis., 2017, 69, 696-700.

2 C. Toquero and S. Bolado, Bioresour. Technol., 2014, 157, 6876.

3 W. Zhuang, L. He, J. Zhu, R. An, X. Wu, L. Mu, X. Lu, L. Lu, X. Liu and H. Ying, Int. J. Hydrogen Energy, 2015, 40, 36793688.

4 Z. Bedolla-Valdez, Y. Verde-Gomez, A. Valenzuela-Muniz, Y. Gochi-Ponce, M. Oropeza-Guzmán, G. Berhault and G. Alonso-Núñez, Electrochim. Acta, 2015, 186, 76-84.

5 L. Yan, K. Huang, Y. Chen and Y. Xing, ECS Electrochem. Lett., 2014, 3, F27-F29.

6 C. Xu, L. Cheng, P. Shen and Y. Liu, Electrochem. Commun., 2007, 9, 997-1001.

7 C. Xu, H. Wang, P. K. Shen and S. P. Jiang, Adv. Mater., 2007, 19, 4256-4259.

8 N. Kakati, J. Maiti, S. H. Lee, S. H. Jee, B. Viswanathan and Y. S. Yoon, Chem. Rev., 2014, 114, 12397-12429.

9 C.-C. Kung, P.-Y. Lin, Y. Xue, R. Akolkar, L. Dai, X. Yu and C.-C. Liu, J. Power Sources, 2014, 256, 329-335.

10 I. A. Rutkowska, A. Wadas and P. J. Kulesza, Electrochim. Acta, 2016, 210, 575-587.

11 E. J. Lim, Y. Kim, S. M. Choi, S. Lee, Y. Noh and W. B. Kim, J. Mater. Chem. A, 2015, 3, 5491-5500.

12 V. Baglio, D. Sebastián, C. D'Urso, A. Stassi, R. Amin, K. ElKhatib and A. Aricò, Electrochim. Acta, 2014, 128, 304-310.

13 X. Fang, L. Wang, P. K. Shen, G. Cui and C. Bianchini, J. Power Sources, 2010, 195, 1375-1378.

14 Y. Wang, S. Zou and W.-B. Cai, Catalysts, 2015, 5, 1507-1534.

15 J. Tayal, B. Rawat and S. Basu, Int. J. Hydrogen Energy, 2012, 37, 4597-4605.

16 S. T. Nguyen, Y. Yang and X. Wang, Appl. Catal., B, 2012, 113, 261-270.

17 P. A. Delgado, J. P. Brutman, K. Masica, J. Molde, B. Wood and M. A. Hillmyer, J. Appl. Polym. Sci., 2016, 133, 43926.

18 A. Bhatnagar, W. Hogland, M. Marques and M. Sillanpää, Chem. Eng. J., 2013, 219, 499-511.

19 L. Assaud, N. Brazeau, M. K. Barr, M. Hanbücken, S. Ntais, E. A. Baranova and L. Santinacci, ACS Appl. Mater. Interfaces, 2015, 7, 24533-24542.

20 H. Hua, C. Hu, Z. Zhao, H. Liu, X. Xie and Y. Xi, Electrochim. Acta, 2013, 105, 130-136.
21 P. C. Sahoo, K. Kim, J. H. Lee, J.-I. Han and Y.-K. Oh, ACS Sustainable Chem. Eng., 2015, 3, 1764-1770.

22 D.-Y. Zhang, Z.-F. Ma, G. Wang, K. Konstantinov, X. Yuan and H.-K. Liu, Electrochem. Solid-State Lett., 2006, 9, A423A426.

23 X. He, C. Hu, Q. Yi, X. Wang, H. Hua and X. Li, J. Electrochem. Soc., 2013, 160, F566-F572.

24 H. Wang and Q. Ma, J. Electrochem. Soc., 2014, 161, F1202F1207.

25 P. Justin and G. R. Rao, Catal. Today, 2009, 141, 138-143.

26 J. Datta, A. Dutta and M. Biswas, Electrochem. Commun., 2012, 20, 56-59.

27 C. Xia and M. Liu, Adv. Mater., 2002, 14, 521.

28 B. Y. Xia, H. B. Wu, J. S. Chen, Z. Wang, X. Wang and X. W. D. Lou, Phys. Chem. Chem. Phys., 2012, 14, 473-476.

29 Y. Qu, Y. Gao, F. Kong, S. Zhang, L. Du and G. Yin, Int. J. Hydrogen Energy, 2013, 38, 12310-12317.

30 X. Wang, Y. Li, S. Liu and L. Zhang, Nanomaterials, 2016, 6, 40.

31 H. Yoshitake, T. Sugihara and T. Tatsumi, Chem. Mater., 2002, 14, 1023-1029.

32 N. Yamada, T. Hitosugi, N. L. H. Hoang, Y. Furubayashi, Y. Hirose, T. Shimada and T. Hasegawa, Jpn. J. Appl. Phys., 2007, 46, 5275.

33 G. Chen, S. R. Bare and T. E. Mallouk, J. Electrochem. Soc., 2002, 149, A1092-A1099.

34 H. Chhina, S. Campbell and O. Kesler, J. Electrochem. Soc., 2009, 156, B1232-B1237.

35 S. Wang, L. Pan, J.-J. Song, W. Mi, J.-J. Zou, L. Wang and X. Zhang, J. Am. Chem. Soc., 2015, 137, 2975-2983.

36 L. Yan, X. Rui, G. Chen, W. Xu, G. Zou and H. Luo, Nanoscale, 2016, 8, 8443-8465.

37 R. Asahi, T. Morikawa, T. Ohwaki, K. Aoki and Y. Taga, Science, 2001, 293, 269-271.

38 W. P. Davey, Phys. Rev., 1925, 25, 753.

39 S. Maheswari, P. Sridhar and S. Pitchumani, Electrochem. Commun., 2013, 26, 97-100.

40 Y. Zhao, Y. Wang, J. Zang, J. Lu and X. Xu, Int. J. Hydrogen Energy, 2015, 40, 4540-4547.

41 L. Zhang, L. Ji, P.-A. Glans, Y. Zhang, J. Zhu and J. Guo, Phys. Chem. Chem. Phys., 2012, 14, 13670-13675.

42 X. Yue, W. Yang, X. Liu, Y. Wang, C. Liu, Q. Zhang and J. Jia, Electrochim. Acta, 2015, 174, 667-671.

43 Y.-H. Qin, Y. Zhuang, R.-L. Lv, T.-L. Wang, W.-G. Wang and C.-W. Wang, Electrochim. Acta, 2015, 154, 77-82.

44 Q. Lv, M. Yin, X. Zhao, C. Li, C. Liu and W. Xing, J. Power Sources, 2012, 218, 93-99.

45 Y. Zhao, X. Yang, J. Tian, F. Wang and L. Zhan, Int. J. Hydrogen Energy, 2010, 35, 3249-3257.

46 J. Zhu, X. Zhao, M. Xiao, L. Liang, C. Liu, J. Liao and W. Xing, Carbon, 2014, 72, 114-124.

47 A. M. Hofstead-Duffy, D. J. Chen, S. G. Sun and Y. J. Tong, J. Mater. Chem., 2012, 22, 5205-5208.

48 F. Hu, F. Ding, S. Song and P. K. Shen, J. Power Sources, 2006, 163, 415-419. 